\title{
Fiscal Policy in Association with Sustainable Economic Growth in the Period 2011-2020
}

\author{
SỬ ĐÌNH THÀNH \\ University of Economics HCMC - dinhthanh@ueh.edu.vn \\ BÙI THỊ MAI HOÀI \\ University of Economics HCMC - maihoai@ueh.edu.vn \\ MAI ĐİNH LÂM \\ National Academy of Public Administration HCMC - maidinhlam2006@yahoo.com
}

\begin{tabular}{ll} 
ARTICLE INFO & ABSTRACT \\
\hline $\begin{array}{l}\text { Article history: } \\
\text { Received: } \\
\text { Dec. 12, 2013 } \\
\text { Received in revised form } \\
\text { Dec. 26, 2013 }\end{array}$ & $\begin{array}{l}\text { Employing endogenous growth model, panel data from 62 provinces } \\
\text { and cities in 2000-2011 and PMG and Arellano-Bond difference } \\
\text { GMM, the research analyzes empirically the relationship between the } \\
\text { fiscal policy and economic growth in Vietnam. Its main findings are: } \\
\text { (i) fiscal decentralization and economic growth cointegrate in the long }\end{array}$ \\
Marcepted: & $\begin{array}{l}\text { run, but government's efforts to adjust its fiscal policy during } \\
\text { economic shocks that cause disequilibrium or make the economy } \\
\text { Meviate from its long-term trend produce very low effects; (ii) fiscal }\end{array}$ \\
& $\begin{array}{l}\text { income decentralization and fiscal support have positive effects on } \\
\text { economic growth while expenditure decentralization does not; (iii) } \\
\text { current expenditure and spending on education, scientific research, } \\
\text { health care and environmental issues produce positive effects on the } \\
\text { economic growth while public investment fails to do so. }\end{array}$ \\
$\begin{array}{l}\text { Keywords: } \\
\text { fiscal policy, fiscal } \\
\text { decentralization, economic } \\
\text { growth. }\end{array}$ &
\end{tabular}




\section{INTRODUCTION}

In the economic reform, the fiscal policy has been focused on raising efficient allocation of public resources for sustainable growth. The 1996 National Budget Law amended in 2002 laid a sound foundation for the principles of reforms in fiscal management and decentralization. Decentralization - the transfer of administrative, fiscal and political power to local authorities - has emerged as a major trend in the adoption of development policy in Vietnam. A change in fiscal power and responsibility may increase economic efficiency as local governments have better information about resource allocation than the central government does (Oates, 1993). Moreover, fiscal decentralization, despite being a local solution, contributes actively to the recovery from the global recession.

As with decentralization policy, the government has made adjustments to fiscal policy to link it with programs and projects aimed at poverty alleviation. To increase growth in the future, growth capability must be reinforced, resulting in the introduction of policies on education, health care, scientific and environmental research into the national agenda. As a result, during the period 2001-2010, the average economic growth rate reached $7.26 \%$.

Vietnam's Socioeconomic Development Strategy for 2011-2020 continues to set an average growth rate of $7 \%-8 \%$ yearly as its main target. Therefore, a sustainable growth model has been developed. However, during the period, the government faces a conflict between a large and growing demand for improvements in aforementioned fields and the lack of plans to raise taxes while they are even cut down due to integration requirements. The likely solution is to effectively enhance the allocation of public resources on the basis of fiscal decentralization policy, and the possibility to increase the quantity and quality of public services greatly depends on a fair and effective system of fiscal decentralization (Martinez-Vazquez \& Gomez, 2005).

The research aims to answer the following questions: (i) Is there a long-term cointegration relationship between fiscal decentralization and economic growth? (ii) What effects do fiscal decentralization and its components have on economic growth? (iii) How do expenditure components contribute to economic growth? To conduct the research, empirical theories on economic growth are viewed on the local level, focusing on fiscal decentralization and public expenditure components. Along with Pooled Mean 
Group (PMG) and Generalized Methods of Movements (GMM) methods, the research also employs panel data of 62 provinces/cities of Vietnam in the period 2000-2011.

The remainder of the paper includes: section 2 carrying out an evaluation of theories and empirical researches, section 3 giving an outline of fiscal decentralization policy in Vietnam, section 4 introducing an analytical framework and empirical model, section 5 discussing research data, section 6 presenting research results, and section 7 offering conclusions and policy implications.

\section{LITERATURE REVIEW}

Sustainable economic growth in this research is viewed in terms of growth sustained in the long run, thereby improving social welfare. Fiscal policy is part of macroeconomic policy, reflecting the ways the central government use public expenditure, tax collection, loans, and fiscal decentralization to exert an impact on economic activities. Fiscal decentralization is defined as the transfer of rights to collect taxes and decisions on public expenditures from central to local governments (Prud'homme, 2001; MartinezVazquez \& Gomez, 2005).

Most researches on the relationship between fiscal decentralization and economic growth are based on the assumption that fiscal policy impacts on the growth through economic efficiency. Based on an endogenous growth model with public expenditure distributed among different levels of authorities, Xie et al. (1999) analyze the impact of fiscal decentralization on long-term economic growth in the U.S. from 1948 to 1994. The results show that decentralization of public expenditure between federal and state governments currently maximizes the growth but imply that further increases would impair it. Behnisch et al. (2002) support this argument for the case of developed economies, confirming that diminution in fiscal decentralization or increase in public expenditure by the federal government has a positive impact on overall productivity in the German economy in the period 1950-1990.

So what is the implication on developing economies? Feltenstein \& Iwata (2005) support the theory of fiscal decentralization based on the findings of the positive impact of fiscal decentralization on China's growth in the postwar period. Malik et al. (2006) and Faridi (2011) also find empirical evidence of the positive impact in case of Pakistani economic growth in the two periods - from 1971 to 2005 and from 1972 to 2009. However, in the partial analysis model, Philip \& Isah (2012) find a case of negative 
impact of fiscal decentralization on Nigeria's economic growth. Thus, the impact of fiscal decentralization is not the same over developing economies.

The impact is dependent on the economic context (Romero \& Strauch, 2008; Phillips \& Woller, 1998; Davoodi \& Zou, 1997). Employing a dataset of 23 developing countries and 17 developed ones in the period 1974-1991, Phillips \& Woller (1998) demonstrate a negative effect of revenue decentralization on economic growth among developed countries but do not show any relationship between fiscal decentralization and the growth. Davoodi \& Zou (1998) use the panel data of 46 countries in the period 19701989 to examine the relationship between fiscal decentralization and economic growth. In their surveyed sample, developed countries have higher levels of fiscal decentralization than developing ones (33\% compared to 20\%). The results indicate a negative relationship between fiscal decentralization and growth in developing countries, which does not exist in developed ones.

Many researches on fiscal policy and growth emphasize the importance of public governance. Analyzing the relationship between fiscal decentralization and economic growth of 23 OECD countries from 1975 to 2001, Baskaran \& Feld (2009) find that revenue decentralization has no connection with the growth. There implies a need to distinguish between political autonomy and fiscal autonomy for local governments when implementing decentralization programs. The degree of the former higher than that of the latter seemingly hinders the growth due to increasing ideological conflicts. From this aspect, fiscal autonomy has a close relationship with local governance and the cooperation among authorities of different levels. Adopting a dataset of 30 countries, deMello (2000) confirms a failure in inter-governmental fiscal cooperation resulting in prejudices about fiscal deficit in the decision-making process, especially in case of developing countries where basic requirements of decentralization policy are not met.

With data of 28 provinces in China from 1980 to 1992, Zhang \& Zou (1998) demonstrate a high level of expenditure decentralization during the economic transition in parallel with a low economic growth rate of the local economy. Similarly, using data of 30 provinces in China in two phases - from 1979 to 1993 (under the fiscal contract system) and from 1994 to 1999 (under the tax assignment system), Jin \& Zou (2005) figure out no growth benefit from fiscal decentralization. Decentralization of revenue does create an incentive to expand local sources of revenue and centralization of expenditure promotes the growth better because the central government uses public 
expenditure more efficiently than provincial ones. Policy implication here is that the effects of fiscal decentralization in any case depend mainly on the rationality of the nature of fiscal institutions, inter-governmental relations in the political system and other national attributes such as history, culture, and the likes. Based on this view, Akai \& Sakata (2002) come up with new findings on the contribution of fiscal decentralization to economic growth in the US.

There are many researches on the impact of fiscal policy on Vietnam's economic growth. Based on data collected from 31 localities during the period 2004-2005 and POLS estimation method, Hoàng et al. (2010) suggest that expenditure on investment at district level should be higher, while that at provincial level should be reduced to promote local economic growth. Pham (2008) analyzes the structure of public expenditure and growth with data collected from 61 provinces/cities in Vietnam from 2001 to 2005. Employing POLS method, his research discovers public investment has a more positive impact than current expenditure on agriculture, forestry, fisheries, education and training, and health care. On the contrary, by means of fixed effects and random effects models with data of 61 localities from 2000 to 2005, Nguyễn (2009) clarifies a positive impact from revenue decentralization and a negative impact from current and investment expenditure on local economic growth in Vietnam.

\section{ECONOMETRIC MODELS}

\section{a. Dynamic Model of Fiscal Decentralization and Economic Growth:}

Based on the analytical framework by Barro (1990), a dynamic model with panel data is developed, including a dependent variable - GDP per capita - and a set of independent variables. GDP per capita is measured by dividing the gross regional product (GRP) in current prices by the total population of the province. This is used to compare the level of development among provinces and serve as an indicator of living standards. The set of independent variables includes the following:

\section{(1) Fiscal matter and fiscal decentralization}

Fiscal decentralization is decided by both revenue and expenditure assignment. Expenditure decentralization is measured by the ratio of provincial budget expenditure to national budget expenditure (Jin \& Zou, 2005; Barro, 1990) per capita (Zhang \& Zou, 1998). Similarly, revenue decentralization is defined as the ratio of provincial budget revenue to national budget revenue (per capita). Revenue and expenditure 
decentralization must be theoretically compatible to promote economic growth. Nearly 50 provinces/cities in Vietnam cannot achieve budget balance and have to rely on fiscal support, which is, as a result, included in the model as a variable to assess its potential effects and measured by the amount of grant-in-aid compared to total local budget expenditure.

\section{(2) Set of control variables}

To control impacts of other variables apart from fiscal ones, a number of control variables is introduced into the research model to improve its robustness. First, two basic factors of a production process (capital and labor) are calculated by growth rate of private investment and labor growth. Second, based on the theory of taxation in relation to changes in market behavior and creation of social loss, two other variables are introduced to measure distorting effects of central and local governments' taxation (Jin \& Zou, 2005; Zhang \& Zou, 1998; and Barro, 1990), including central tax and local tax, calculated by ratio of national tax revenue to GDP and ratio of provincial tax revenue to GRP respectively. The higher the tax rate, the more the economy is distorted by the fiscal system (Jin \& Zou, 2005; Barro, 1990 cited in Zhang \& Zou, 1998). Finally, trade openness and inflation are employed as control variables. According to traditional hypotheses, the greater the trade openness, the greater its impacts on economic growth (Jin \& Zou, 2005; Feder, 1983 cited in Zhang \& Zou, 1998), and local inflation is used to control potential effects of the instability on economic growth (Jin \& Zou, 2005; Zhang \& Zou, 1998), which can be positively or negatively related.

From the above analysis, a dynamic growth model can be established with provincial data as follows:

$$
Y_{i t}=\beta_{0}+\beta_{1} Y_{i t-1}+\beta_{2} F D_{i t}+\beta_{3} \text { FTAX }_{i t}+\beta_{4} L T A X_{i t}+\beta_{5} \text { CONTROL }_{i t}+e_{i t}
$$

where

$i$ : province/city, $t$ : time;

Y: Log of gross regional products (GRP) per capita, a variable representative of growth

FD: fiscal decentralization, comprising the following variables:

- FDEX: provincial budget expenditure divided by national budget expenditure (per capita) (provincial budget expenditure: investment expenditure and current expenditure), representative of expenditure decentralization 
- FDREV: provincial budget revenue divided by national budget revenue (per capita) (provincial budget revenue: types of revenue totally retained by the provincial government and others divided between central and provincial governments), representative of revenue decentralization

- SUBSI: amount of grant-in-aid, or subsidy, divided by total provincial budget expenditure, representative of fiscal support

TAX: degree of distortion by tax, measured by two variables:

- FTAX: total tax revenue for central budget divided by GDP

- LTAX: total tax revenue for provincial budget divided by GRP

CONTROL $\mathrm{L}_{\mathrm{it}}$ : a set of the following variables:

- LnPINVES: log of private investment, measuring the growth of private investment

- HUM: growth rate of employed population in the province

- CPI: provincial consumer price index, representing provincial inflation rate

- OPEN: total export value plus total import value divided by GRP (converted to the USD at the average exchange rate), measuring local trade openness.

Dynamic model of fiscal expenditure components and economic growth:

To test the impact of public expenditure components on growth and based on Kneller et al. (1998), the following model is applied:

$$
Y_{i t}=\beta_{0}+\beta_{1} Y_{i t-1}+\sum_{j}^{m} \beta_{j} X_{j t}+\beta_{3} \text { FTAX }_{i t}+\beta_{4} L T A X_{i t}+\beta_{5} \text { CONTROL }_{i t}+e_{i t}
$$

FTAX and LTAX help measure distortionary taxation and reflect budget constraint (Kneller et al., 1998). $X$ comprises the following variables:

LnINVEX: Log of provincial investment expenditure

LnCURREX: Log of provincial current expenditure

LnEDU: Log of expenditure on education and vocational training

LnHE: Log of expenditure on health care

LnRD: Log of expenditure on science, technology and environment

LnSS: Log of expenditure on social security

LnECO: Log of expenditure on economic activities 
LnAD: Log of expenditure on administration

\section{ESTIMATION METHODS}

To give an answer to the first research question, PMG (Pooled Mean Group) by Pesaran et al. (1999) is applied in the research. By groups and directions of the panel, PMG method has many advantages in handling heterogeneity in the short and long term. The method allows: (i) estimating long-term elasticity of variables fiscal decentralization and economic growth, and (ii) testing the speed of adjustment to the long-run equilibrium.

PMG is also to estimate the following error correction model of variables collectively named LF (including local taxes, revenue decentralization, expenditure decentralization, and fiscal support) and economic growth:

$$
\Delta Y_{i t}=\phi_{i} S_{i t-1}+\sum_{j=1}^{m} \delta_{i j} \Delta L F_{i t-j}+\mu_{i}+e_{i t} ; \text { and } S_{i t-1}=Y_{i t-1}-\theta L F_{i t-1} .
$$

where

$S_{i t-1}:$ long-term equilibrium

$\phi$ : error correction coefficient

$\theta$ : long-term elasticity of $\mathrm{Y}$ (economic growth) with respect to variables related to local fiscal affairs

$\delta$ : coefficient of short-term reaction of fiscal decentralization variables to economic growth

$\mu_{i}$ : fixed effect of each locality (i) and error $\left(e_{i t}\right)$

To answer questions 2 and 3, GMM method is adopted, allowing equation (3.1) to be estimated with the method of fixed effects (FE):

$$
Y_{i t}=\left(\beta_{0}+v_{i}\right)+\beta_{1} Y_{i t-1}+\beta_{2} F D_{i t}+\beta_{3} F T A X_{i t}+\beta_{4} L T A X_{i t}+\beta_{5} C O N T R O L_{i t}+e_{i t}
$$

However, when lag variables are included in the model (4.1), FE estimation will be biased due to the short time series (T) (Judson \& Owen, 1999). The research, therefore, proceeds to use GMM (Difference Generalized Method of Moments) by Arellano \& Bond (1991), which is appropriately designed for panel data with short T and large N (Judson \& Owen, 1999; Roodman, 2006). In GMM, it is necessary to distinguish 
between instrumented and instrument variables. Assumed endogenous variables should be included in the group of instrumented ones by their lag value, whereas explanatory variables, defined as strictly exogenous ones as well as additional instruments (if any), are classified as instrument variables (IV). Current and lag values of the assumed exogenous variables are all appropriate tools (Judson \& Owen, 1999).

The rationality of the instruments used in GMM is assessed through Sargan and Arellano-Bond test statistics. As for Sargan test with hypothesis H0, the instrument variables are exogenous, that is, uncorrelated with errors. Thus, the p-value of Sargan statistics should be as large as possible. On the other hand, Arellano-Bond test is used to check the autocorrelation of errors in the form of first difference. Thus, the difference series automatically has first-ordered correlation - AR(1) - the test results can be ignored. Second-ordered correlation - AR(2) - is tested on the difference series of the errors to find out autocorrelation of errors in first order - AR(1).

\section{DATA}

Based on the research model, yearly data in the period 2000-2011 are collected from General Statistics Office, including those of the whole country and 64 provinces/cities in Vietnam. The data, therefore, are consistent and reliable enough to perform testing. They are processed and transformed to become suitable to the nature of variables in the quantitative model. In that process, the case of Quảng Ngãi Province is eliminated due to insufficient data on revenue and expenditure of local budget in the period 2000-2011. Furthermore, Hà Tây Province and Hà Nội were merged in 2007, resulting in the merged data of these two localities. Panel data, accordingly, have $\mathrm{T}=12$ and $\mathrm{N}=62$ provinces/cities with the total number of observations being 744. However, statistics of such localities as Hà Nội, Lai Châu, Bình Thuận, and Đắk Lắk for several years are lacking, and as a result, the number of observations for variables relating to provincial budget expenditure (on education, health care and scientific research, etc.) is not 744 , as illustrated in Table 1. 
Table 1: Statistical Description of the Variables in the Model

\begin{tabular}{|c|c|c|c|c|c|}
\hline Variable & Obs & Mean & Std. Dev. & Min & $\operatorname{Max}$ \\
\hline Economic growth $(\mathrm{Y})$ & 744 & 9.0430 & .79969 & 7.2877 & 12.1400 \\
\hline Central tax (FTAX) & 744 & .26046 & .03008 & .20088 & .28876 \\
\hline Local tax (LTAX) & 744 & .12448 & .07776 & .01548 & .70420 \\
\hline $\begin{array}{l}\text { Expenditure decentralization } \\
\text { (FDEX) }\end{array}$ & 744 & .53682 & .23193 & .14408 & 1.8888 \\
\hline $\begin{array}{l}\text { Revenue decentralization } \\
\text { (FDREV) }\end{array}$ & 744 & .35714 & .21607 & .04960 & 1.4576 \\
\hline $\begin{array}{l}\text { Investment expenditure } \\
\text { (LnINVEX) }\end{array}$ & 744 & 6.3422 & .93883 & 2.9711 & 9.9687 \\
\hline $\begin{array}{l}\text { Current expenditure } \\
\text { (LnCURREX) }\end{array}$ & 744 & 6.9782 & .81398 & 4.1006 & 9.9725 \\
\hline Fiscal support (SUBSI_R) & 744 & .56628 & .32142 & .00691 & 2.2227 \\
\hline Education (LnEDU) & 732 & 6.0752 & .80877 & 3.8567 & 9.0035 \\
\hline Health care (LnHE) & 729 & 4.6978 & .92545 & 2.9512 & 7.6901 \\
\hline Scientific research (LnRD) & 729 & 2.1784 & .78662 & .10436 & 5.5279 \\
\hline Social security (LnSS) & 729 & 3.8098 & 1.0181 & 1.0338 & 6.9902 \\
\hline Economic activities (LnECO) & 731 & 4.6810 & .89057 & 1.9911 & 7.8973 \\
\hline Administration (LnADM) & 731 & 5.3597 & .82778 & 2.1257 & 7.8592 \\
\hline Trade openness (OPEN) & 744 & .65436 & .98264 & .00068 & 7.7743 \\
\hline $\begin{array}{l}\text { Private investment } \\
\text { (LnPRINVES) }\end{array}$ & 744 & 7.4031 & 1.2454 & 4.1913 & 11.598 \\
\hline Inflation (CPI) & 744 & 108.7768 & 6.7676 & 93.4 & 136.88 \\
\hline Human resource (HUM) & 744 & 102.3203 & 3.7321 & 84.89 & 122.18 \\
\hline
\end{tabular}

\section{RESEARCH RESULTS}

Unit root test on variables local fiscal matter and economic growth is initially performed, including Fisher, Im-Pesaran-Shin (IPS) and Levin-Lin-Chu (LLC) tests. The results show that the local tax is stationary, or I(0) (i.e. integrated of order zero) in 
all types of test and the rest are stationary in at least two types. The variable economic growth is only non-trend stationary in IPS test. Next, the cointegration of fiscal decentralization and economic growth is tested, based on residuals from the regression equation $Y_{i t}=\alpha_{i}+\mu_{i}+\beta X_{i t}+\varepsilon_{i t}$ as recommended by McCoskey \& Kao (1998) and Larson et al. (2001) when the panel data contain a short T. This is a fixed effects regression model, where $\mathrm{Y}$ is economic growth, $\mathrm{X}$ is the set of variables related to local fiscal components, $\alpha_{i}$ is detailed intercept of each locality, $\mu_{t}$ is a vector of variables unchanged over time, and $\varepsilon_{i t}$ is error. The cointegration is supported when $\varepsilon_{i t}$ is integrated of order zero, $\mathrm{I}(0)$.

\section{Table 2: Results of Tests on Long- and Short-term Dynamism of Fiscal Decentralization}

Long-term cointegrating vectors

Dependent variable: Economic growth (Y)

\begin{tabular}{lcc}
\hline \multicolumn{1}{c}{ Variables } & Coeff. & Std. \\
\hline Local tax & $-20.958^{* * *}$ & 1.858 \\
Revenue decentralization & $6.859^{* * *}$ & 0.456 \\
Expenditure decentralization & $-5.097^{* * * *}$ & 0.459 \\
Fiscal support & $7.578^{* * *}$ & 0.629 \\
\hline Short-term dynamism & & \\
\hline Error correction & $0.020^{* * *}$ & 0.005 \\
$\Delta$ local tax & $-5.032^{* * * *}$ & 0.770 \\
$\Delta$ revenue decentralization & $1.606^{* * *}$ & 0.244 \\
$\Delta$ expenditure decentralization & -0.010 & 0.098 \\
$\Delta$ fiscal support & -0.008 & 0.050 \\
Cons & -0.008 & 0.043 \\
Obs & & 682 \\
Log Likelihood & & \\
\hline
\end{tabular}

Note: $(* * *)$ significance at $1 \%$ 
The test results governed by Fisher, IPS and LLC methods show the residual $(\varepsilon)$ is trend and non-trend stationary, or integrated of order zero, $\mathrm{I}(0)$ with a significance level of $1 \%$. Thus, testing results suggest the existence of cointegration between the fiscal decentralization and economic growth. Finally, error correction model (ECM) is estimated by applying the PMG method. The estimation results are presented in Table 2. In a long term, local tax and expenditure decentralization have negative relationships with economic growth, whereas revenue decentralization and fiscal support are positively related to economic growth. Error correction coefficient (EC) is statistically significant, but its positive and too small value (0.02) shows that government's efforts to adjust its fiscal policy during economic shocks that cause disequilibrium or make the economy deviate from its long-term trend only produced very poor results. Regarding short-term dynamism, revenue decentralization is also positively related to economic growth, whereas local tax is negatively related while the remaining variables are statistically insignificant.

\section{b. Impact of Fiscal Decentralization on Economic Growth:}

GMM is applied to the estimation along with the use of instrument variables. Table 3 gives statistics of these variables.

GEO: reflecting local geographical features and measuring characteristics of municipality/zone (special municipalities are encoded as 6; centrally controlled ones, 5; municipalities in key economic zones, 2-4; and provincial municipalities, 1).

WEALTH: measuring the local wealth, based on proportion of its revenue sent to the central budget. This proportion may vary from over $60 \%, 50-60 \%, 10-50 \%$, to under $10 \%$ and is encoded 4, 3, 2, and 1 respectively; and otherwise, 0 .

LOCALSIZE: reflecting the size of localities based on their area, equaling their natural area divided by 2,000 square $\mathrm{km}$ (according to guidelines on fiscal decentralization scoring).

GEO*FDEX: reflecting characteristics of municipality or zone integrated with revenue decentralization.

GEO*WEALTH*FDEX: reflecting characteristics of municipality or zone integrated with level of local development and revenue decentralization.

Table 3 reports regression results with GMM application, which by turns considers each component of the fiscal decentralization variables. Revenue decentralization is 
shown to positively relate to economic growth (significant at 5\%). Fiscal support positively relates to the latter, suggesting the "flypaper effect" by Hines \& Thaler (1995) in the use of grant-in-aid by local governments. The impact of expenditure decentralization is statistically insignificant, thereby indicating that the link between revenue and expenditure decentralization with economic growth, in Vietnam, does not support the theory of fiscal decentralization at all. The impact of revenue decentralization implies that it may create an incentive to expand local sources of revenue and improve the overall fiscal situation (Shah, 1994 cited by Jin \& Jou, 2005).

It is noteworthy that characteristics of municipality/zone when integrated with expenditure decentralization produce a positive effect on economic growth at a significant level of 5\% (model 4). This implies that expenditure decentralization with characteristics of municipality/zone taken into account have a certain significance to local growth. Another notable result is that local tax causes distortions to growth at $1 \%$ significance level, while central one does not. Additionally, all control variables in the model obtain expected results. Labor positively contributes to local growth at 5\% significance level. The regression coefficients of the variables private investment and inflation positively affect economic growth with significance at $1 \%$ while relationship between trade openness and local growth is not found.

In model (4), $p$-value of Sargan statistics is 0.206, which confirms that the instruments used in the GMM are exogenous and not correlated with residuals. Arellano - Bond AR(2) test with $p$-value equal 0.649 shows that the variables in the model have no autocorrelation.

\section{c. Impact of Public Expenditure Components on Economic Growth:}

Firstly, based on the analysis by Kneller et al. (1998), equation (3.2) can be rewritten as follows:

$$
Y_{i t}=\beta_{0}+\beta_{1} Y_{i t-1}+\sum_{j=1}^{m-1} \beta_{j} X_{j t}+\beta_{3} F_{T A X}+\beta_{4} L T A X_{i t}+\beta_{5} \text { CONTROL }_{i t}+e_{i t}
$$

In fact, if $m$ represents all budget revenue or expenditure factors under examination, then $\sum_{j}^{m} X_{j t}=0$. Then, at least one factor in $\mathrm{X}$-set should be eliminated to avoid multicollinearity (Kneller et al., 1999). Secondly, among control variables, we pay attention to lags of private investment (LnPINVES) and inflation (CPI). Previous value 
expectations of variables are added to lags. Results of estimation are presented in Table 4.

Model 1 considers public expenditure components including investment expenditure (LnINVEX) and current expenditure (LnCURREX). Results suggest that the latter promotes economic growth, while the impact of the former is not significant. The variable investment expenditure remains in Models 2 and 3, while such variables as expenditure on education and vocational training (LnEDU), expenditure on scientific research and environment (LnRD) and expenditure on health care (LnHE) take turns to take the place of current expenditure, all of which do affect economic growth (Model 3). Also in Model 3, the effect of investment expenditure is not significant. Models 4, 5 and 6 retain all variables, introducing such new ones as expenditure on social security (LnSS), expenditure on economic activities (LnECO), and expenditure on administration (LnAD). The relationships between the previous variables and economic growth remain unchanged with significance at $1 \%$ and $5 \%$ (Model 6). The impact of newly introduced variables and investment expenditure is statistically insignificant.

In the aforementioned models, the impact of central and local tax on economic growth is negative, whereas that of private investment and inflation is positive; the impact of labor and trade openness is statistically insignificant. The $p$-value of Sargan statistics in the models maintains that the instruments applied in GMM are exogenous. Results of Arellano-Bond $\mathrm{AR}(2)$ test show that the variables have no autocorrelation.

\section{CONCLUSION AND POLICY IMPLICATIONS}

Based on the endogenous growth model, the research examines the relationship between fiscal policy and economic growth in Vietnam by employing the methods PMG and GMM. The results indicate the following:

- There exists a cointegration relationship between fiscal decentralization and economic growth in the long run. When the economy, however, deviates from its longterm equilibrium, the government's efforts in adjusting fiscal policy bring about poor results.

- Regarding the fiscal decentralization, revenue decentralization and fiscal support have positive relationships with economic growth in the long run, whereas expenditure decentralization is negatively related. With such findings, the traditional theory that fiscal decentralization, especially revenue one, must be closely connected with local 
expenditure demands is not universally applicable in Vietnam. This finding is different from the ones by Phạm (2008) and Nguyễn et al. (2010) but supports those by Nguyễn (2009) and Jin \& Zou (2005). In addition, the research results not just argue for a perspective that revenue expenditure stimulates development of local sources of revenue (Jin \& Zou, 2005) but imply that expenditure centralization boosts the growth as central government monitors its expenditure more effectively than local ones, particularly on major infrastructure projects (Zhang \& Zou, 1998). The estimation results presented in Table 4 show that impact of investment expenditure on local economic growth is not statistically significant. 


\section{Table 3: Regression of Fiscal Decentralization and Economic Growth}

Dependent variable: Economic growth (Y)

\begin{tabular}{|c|c|c|c|c|c|c|c|c|c|c|c|c|}
\hline \multirow[t]{2}{*}{ Variable } & \multicolumn{3}{|c|}{$\begin{array}{l}\text { GMM Estimation } \\
\text { (Model 1) }\end{array}$} & \multicolumn{3}{|c|}{$\begin{array}{l}\text { GMM Estimation } \\
\text { (Model 2) }\end{array}$} & \multicolumn{3}{|c|}{$\begin{array}{l}\text { GMM Estimation } \\
\text { (Model 3) }\end{array}$} & \multicolumn{3}{|c|}{$\begin{array}{c}\text { GMM Estimation } \\
\text { (Model4) }\end{array}$} \\
\hline & Coeff. & $\begin{array}{l}\text { Std. } \\
\text { dev. }\end{array}$ & Prob. & Coeff. & $\begin{array}{l}\text { Std. } \\
\text { dev. }\end{array}$ & Prob. & Coeff. & $\begin{array}{l}\text { Std. } \\
\text { dev. }\end{array}$ & Prob. & Coeff. & $\begin{array}{l}\text { Std. } \\
\text { dev. }\end{array}$ & Prob. \\
\hline Economic growth $(-1)$ & .912 & .042 & $0.00 * * *$ & .906 & .035 & $0.00 * * *$ & .873 & .034 & $0.00 * * *$ & .871 & .033 & $0.00 * * *$ \\
\hline Private investment & .079 & .034 & $0.02 * *$ & .078 & .028 & $0.00 * * *$ & .102 & .027 & $0.00 * * *$ & .108 & .026 & $0.00 * * *$ \\
\hline Labor & .001 & .000 & $0.09 *$ & .001 & .000 & $0.06 *$ & .001 & .000 & $0.03 * *$ & .002 & .001 & $0.03 * *$ \\
\hline Central tax & .251 & .143 & $0.08^{*}$ & .440 & .139 & $0.00 * * *$ & .226 & .145 & $0.07 *$ & .337 & .148 & $0.02 * * *$ \\
\hline Local tax & -.141 & .068 & $0.03 * *$ & -.450 & .167 & $0.00 * * *$ & -.593 & .158 & $0.00 * * *$ & -.583 & .167 & $0.00 * * *$ \\
\hline Expenditure & & & & .058 & .060 & 0.33 & .080 & .062 & 0.19 & -.122 & .097 & 0.20 \\
\hline Revenue decentralization & & & & .146 & .075 & $0.05^{* *}$ & .178 & .072 & $0.01 * *$ & .169 & .079 & $0.03 * *$ \\
\hline Fiscal support & & & & & & & .085 & .026 & $0.07 *$ & .051 & .029 & $0.08 *$ \\
\hline Trade openness & -.061 & .019 & $0.00 * * *$ & -.044 & .018 & $0.01 * *$ & -.022 & .019 & 0.23 & -.023 & .019 & 0.23 \\
\hline Inflation & .006 & .006 & $0.00 * * *$ & .000 & .000 & $0.00 * * *$ & .006 & .000 & $0.00 * * *$ & .007 & .000 & $0.00 * * *$ \\
\hline \multicolumn{10}{|c|}{ Municipality characteristics *fiscal decentralization } & .076 & .030 & $0.01 * * *$ \\
\hline \multicolumn{10}{|c|}{ Municipality characteristics *degree of development $*$ fiscal decentralization } & .008 & .017 & 0.63 \\
\hline Observations & \multicolumn{3}{|c|}{620} & \multicolumn{3}{|c|}{620} & \multicolumn{3}{|c|}{620} & \multicolumn{3}{|c|}{620} \\
\hline Sargan test & \multicolumn{3}{|c|}{0.192} & \multicolumn{3}{|c|}{0.220} & \multicolumn{3}{|c|}{0.259} & \multicolumn{3}{|c|}{0.206} \\
\hline$A R(2)$ & \multicolumn{3}{|c|}{0.555} & \multicolumn{3}{|c|}{0.578} & \multicolumn{3}{|c|}{0.839} & \multicolumn{3}{|c|}{0.649} \\
\hline
\end{tabular}

Note: $* * *, * *$, and $*$ : Statistical sig. level at $1 \% ; 5 \% ; 10 \%$, respectively 
Table 4: Regression of Public Expenditure Components and Economic Growth

Dependent variable: Economic growth (Y)

\begin{tabular}{|c|c|c|c|c|c|c|c|c|c|c|c|c|}
\hline & \multicolumn{2}{|c|}{ Model 1} & \multicolumn{2}{|c|}{ Model 2} & \multicolumn{2}{|c|}{ Model 3} & \multicolumn{2}{|c|}{ Model 4} & \multicolumn{2}{|c|}{ Model 5} & \multicolumn{2}{|c|}{ Model 6} \\
\hline & Coeff. & Prob. & Coeff. & Prob. & Coeff. & Prob. & Coeff. & Prob. & Coeff. & Prob. & Coeff. & Prob. \\
\hline $\begin{array}{l}\text { Economic } \\
\text { growth }(-1)\end{array}$ & .005 & .959 & .213 & $.009 *$ & .256 & $.000 *$ & .246 & $.000 *$ & .248 & $.000 *$ & .255 & $.000 *$ \\
\hline $\begin{array}{l}\text { Private } \\
\text { investment }\end{array}$ & .376 & $.000 *$ & .327 & $.000^{*}$ & .274 & $.000 *$ & .273 & $.000 *$ & .272 & $.000 *$ & .290 & $.000 *$ \\
\hline $\begin{array}{l}\text { Private } \\
\text { investment (-1) }\end{array}$ & .070 & $.001 * * *$ & .060 & $.001 * * *$ & .054 & $.001 * * *$ & .052 & $.001 * * *$ & .052 & $.001 * * *$ & .054 & $.001 * * *$ \\
\hline Labor & .002 & .155 & .001 & .214 & .001 & .198 & .001 & .166 & .001 & .159 & .001 & .120 \\
\hline Central tax & -1.130 & $.001 * * *$ & -.878 & $.001 * * *$ & -.536 & $.036 * *$ & -.496 & $.053 * * *$ & -.500 & $.053^{*}$ & -.440 & $.106 *$ \\
\hline Local tax & -.507 & $.000 * * *$ & -.397 & $.000 * * *$ & -.334 & $.001 * * *$ & -.346 & $.000 * * *$ & -.347 & $.000 * * *$ & -.373 & $.000 * * *$ \\
\hline $\begin{array}{l}\text { Investment } \\
\text { expenditure }\end{array}$ & .023 & .658 & .019 & .288 & .0154 & .350 & .015 & .360 & .015 & .357 & .016 & .333 \\
\hline $\begin{array}{l}\text { Current } \\
\text { expenditure }\end{array}$ & .396 & $.000 * * *$ & & & & & & & & & & \\
\hline $\begin{array}{l}\text { Expenditure on } \\
\text { education }\end{array}$ & & & .209 & $.000 * * *$ & .144 & $.017 * *$ & .145 & $.016^{* *}$ & .148 & $.014 * *$ & .124 & $.037 * *$ \\
\hline $\begin{array}{l}\text { Expenditure on } \\
\text { science and } \\
\text { environment }\end{array}$ & & & .085 & $.007 * * *$ & .076 & $.005 * * *$ & .074 & $.006 * * *$ & .076 & $.004 * * *$ & .082 & $.002 * * *$ \\
\hline $\begin{array}{l}\text { Expenditure on } \\
\text { health care }\end{array}$ & & & & & .085 & $.015^{* *}$ & .085 & $.014 * *$ & .081 & $.021 * *$ & .089 & $.015 * *$ \\
\hline
\end{tabular}


36 | Sử Đình Thành, Bùi Thị Mai Hoài \& Mai Đình Lâm | 19 - 40

\begin{tabular}{|c|c|c|c|c|c|c|c|c|c|c|c|c|}
\hline $\begin{array}{l}\text { Expenditure on } \\
\text { social security }\end{array}$ & & & & & & & .012 & .163 & .012 & .179 & .014 & .154 \\
\hline $\begin{array}{l}\text { Expenditure on } \\
\text { economic } \\
\text { activities }\end{array}$ & & & & & & & & & -.000 & .966 & -.000 & .985 \\
\hline $\begin{array}{l}\text { Expenditure on } \\
\text { administration }\end{array}$ & & & & & & & & & & & -.021 & .256 \\
\hline Trade openness & .003 & .833 & .001 & .910 & -.001 & .940 & -.000 & .980 & -.000 & .998 & -.001 & .945 \\
\hline Inflation & .003 & $.000 * * *$ & .004 & $.000 * * *$ & .004 & $.000 * * *$ & .004 & $.000^{* * *}$ & .004 & $.000 * * *$ & .004 & $.000 * * *$ \\
\hline Inflation (-1) & .001 & $.034 * *$ & .000 & .179 & .001 & .100 & .001 & .130 & .001 & .134 & .001 & .138 \\
\hline Observations & 620 & & 610 & & 609 & & 609 & & 609 & & 609 & \\
\hline Sargan test & 0.676 & & 0.182 & & 0.725 & & 0.809 & & 0.795 & & 0.836 & \\
\hline $\mathrm{AR}(2)$ & 0.604 & & 0.310 & & 0.278 & & 0.344 & & 0.332 & & 0.339 & \\
\hline
\end{tabular}

Note: $* * *, * *$, and $*$ : Statistical sig. level at $1 \% ; 5 \% ; 10 \%$, respectively 
- Given public expenditure components, the impact of expenditure on education and training, expenditure on health care and expenditure on science and technology are positively related with economic growth. In association with funding and budget constraint, local tax has a negative effect on the growth.

The research results set the grounds for recommendations on fiscal policy innovations associated with sustainable economic growth in the period 2010-2020 as follows:

First, expenditure decentralization should be improved to support sustainable growth. Empirical findings indicate a long-term relationship between fiscal decentralization and growth in Vietnam. However, when associating them with real situations, we find that policy on decentralization of public investment does reveal several limitations, which could be seen in irrational decentralization of investment decisions, the central government's inability to coordinate investment structures among provinces, and low-quality planning thus resulting in waste and scattered investment.

The apparent solution is better defined decentralization of investment on basic constructions (building infrastructure and producing fixed assets) for each level of government. Moreover, it is necessary to enhance the capability of central agencies in management of investment projects in provinces, establish sound mechanisms to efficiently control the mobilization and use of public investment, and enhance transparency and accountability.

Second, distinguishing between urban and rural authorities is essential when performing fiscal decentralization. When combined with the municipality/zone characteristics, expenditure decentralization exerts a positive impact on economic growth. The empirical results also support a focus on such characteristics. In other words, fiscal decentralization for urban authorities should be differentiated from that for rural authorities in order to create favorable conditions for more sustainable economic growth.

Third, transparency and accountability in fiscal allocation and use should be strengthen. Revenue is usually centralized more fully than expenditure with an expenditure gap in fiscal balance bridged by fiscal support through target programs. A meaningful impact of fiscal support on growth is shown, conveying the "Flypaper Effect" in local governments' use of grant-in-aid. The implication is to establish transparency and accountability, functioned as significant mechanisms for forcing local 
governments to employ more effectively grants-in-aid (Hines \& Thaler, 1995; Tanzi \& Zee, 1997; and deMello \& Barenstein, 2001).

Fourth, under the conditions of limited funding, expenditure on administration needs to be controlled, whereas those on education, health care, science and technology should be increased since current expenditure and other public expenditure components have a close relationship with economic growth. In another aspect, the research reveals that expenditures on administration, social security and economic activities have not actively supported growth; thus, institutional reform and/or public administration reform programs are to be reinforced. The fact that local tax has a negative impact on local growth in short and long terms emphasizes the importance of budget balance and allocation in producing positively effects on economic growth in the context of budget constraints (Bose et al., 2007).

Last, fiscal policy should be closely coordinated with monetary policy to ensure equilibrium of economic growth in the long term. The shocks, from empirical results, have been proved to deviate economic growth from its long-term trend and the government's efforts to adjust the policy produce poor results. This supports the view that fiscal policy should be directed to medium- and long-term visions and in good combination with monetary policy to adjust the shocks, creating long-lasting economic equilibrium

\section{References}

Akai, N. \& M. Sakata (2002), "Fiscal Decentralization Contributes to Economic Growth: Evidence from State-level Cross-section Data for the United States”, Journal of Urban Economics, Vol.52, pp.93-108.

Arellano, M. \& S. Bond (1991), "Some Tests of Specification for Panel Data: Monte Carlo Evidence and an Application to Employment Equations", The Review of Economic Studies, Vol.58(2), pp.277-297.

Barro, R.J. (1990), “Government Spending in a Simple Model of Endogenous Growth", The Journal of Political Economy, Vol.98(5), pp.103-125.

Baskaran, T. \& L.P. Feld (2009), "Fiscal Decentralization and Economic Growth in OECD Countries: Is There a Relationship?”, CESifo working paper, No. 2721.

Behnisch, A., T. Büttner \& A. Stegarescu (2002), "Public Sector Centralization and Productivity Growth: Reviewing the German Experience”, ZEW Discussion Papers, No.02-03. 
Bose, N., M.E. Haque \& D.R. Osborn (2007), "Public Expenditure and Economic Growth: A Disaggregated Analysis for Developing Countries”, The Manchester School, Vol.75(5), pp.533556.

Davoodi, H. \& H. Zou (1998), "Fiscal Decentralization and Economic Growth: A Cross-Country Study", Journal of Urban Economics, Vol.43, pp.607-629.

deMello, L.J. (2000), "Fiscal Decentralization and Intergovernmental Fiscal Relations: A CrossCountry Analysis", World Development, Vol.28(2), pp.365-380.

deMello, L.J. \& M. Barenstien (2001), "Fiscal Decentralization and Governance: A Cross-Country Analysis”, IMF Working Paper No. 01/71.

Faridi, M.Z. (2011), “Contribution of Fiscal Decentralization to Economic Growth: Evidence from Pakistan”, Pakistan Journal of Social Sciences, Vol.31(1), pp.1-33.

Feltenstein, A. \& S. Iwata (2005), "Decentralization and Macroeconomic Performance in China: Regional Autonomy Has Its Costs”, Journal of Development Economics, Vol.76, pp.481-501.

Hines, J.R. \& R.H. Thaler (1995) “The Flypaper Effect”, Journal of Economic Perspectives, Vol.9(4), pp.217-226.

Hoàng Thị Chinh Thon, Phạm Thị Hương \& Phạm Thị Thủy (2010), "Tác động của chi tiêu công tới tăng trưởng kinh tế tại Việt Nam”, working paper NC-19, VNU University of Economics and Business, Hà Nội.

Innocentsa, E.E. (2011), "Fiscal Decentralisation: A Local Solution to Recovery from Global Recession”, Procedia - Social and Behavioral Sciences, Vol.24, pp.138-146.

Jin, J. \& H. Zou (2005), "Fiscal Decentralization, Revenue and Expenditure Assignment, and Growth in China", Journal of Asian Economics, Vol.16(6), pp.1047-1064.

Judson, R. \& A.L. Owen (1999), "Estimating Dynamic Panel Data Models: A Practical Guide for Macroeconomists", Economics Letters, Vol.65(1), pp.9-15.

Kneller, R., M.F. Bleaney \& N. Gemmell (1998), "Fiscal Policy and Growth: Evidence from OECD Countries”, Journal of Public Economics, Vol.74(2), pp.171-190.

Larson, R., J. Lyhagen \& M. Löthgren (2001), "Likelihood-Based Cointegration Tests in Heterogeneous Panels", The Econometrics Journal, Vol.4(1), pp.109-142.

Malik, S., M. Hassan \& S. Hussain (2006), ““'Fiscal Decentralization and Economic Growth in Pakistan”, Department of Economics, Bahauddin Zakariya University, Multan, Pakistan.

Martinez-Vazquez, J. \& J. Gomez (2005), "Effective Fiscal Decentralization in VietNam", National Tax Association, Proceedings, Annual Conference on Taxation and Minutes of the Annual Meeting of the National Tax Association, Vol.98, pp. 356-361.

McCoskey, S.K. \& C. Kao (1998), “A Residual-Based Test of the Null of Cointegration in Panel Data”, Econometrics Reviews, Vol.17, pp.57-84. 
Nguyễn Phi Lân \& Phạm Hồng Chương (2008), "Phân cấp quản lý tài khóa và tăng trưởng kinh tế địa phương tại Việt Nam”, Kinh tế \& Phát triển, No.12.

Oates, W.E. (1993), "Fiscal Decentralization and Economic Development", National Tax Journal, Vol.46(2), pp.237-243.

Perasan, M.H., S. Yongcheol \& R.P. Smith (1999), "Pooled Mean Group Estimation of Dynamic Heterogeneous Panels", Journal of the American Statistical Association, Vol.94 (446), pp.621634.

Phạm Thế Anh (2008), "Phân tích cơ cấu chi tiêu chính phủ và tăng trưởng kinh tế ở Việt Nam", working paper NC-03/2008, VNU University of Economics and Business, Hà Nội.

Philip, A.T. \& S. Isah (2012), “An Analysis of the Effect of Fiscal Decentralisation on Economic Growth in Nigeria", International Journal of Humanities and Social Science, Vol.2(8), pp.141149.

Phillips, K.L. \& G. Woller (1998), “Does Fiscal Decentralization Lead to Economic Growth?”, The Journal of Development Studies, Vol.34(4), pp.139-148.

Prud'home (2001), "Fiscal Decentralization and Intergovernmental Fiscal Relation", Symposium on Decentralization Local Governance in Africa.

Romero, D. \& R. Strauch (2008), "Public Finances and Long-term Growth in Europe: Evidence from a Panel Data Analysis”, European Journal of Political Economy, Vol.24, pp.172-191.

Roodman, D. (2006), "How to do xtabond2: An Introduction to Difference and System GMM in Stata", The Strata Journal, Vol.9(1), pp.86-136.

Tanzi, V. \& H.H. Zee (1997), "Fiscal Policy and Long-run Growth”, IMF Staff Papers, Vol.44(2), pp.179-209.

Xie, D., H. Zou \& H. Davoodi (1999), "Fiscal Decentralization and Economic Growth in the United States", Journal of Urban Economics, Vol.45(2), pp.228-239.

Zhang, T. \& H. Zou (1998), "Fiscal Decentralization, Public Spending, and Economic Growth in China”, Journal of Public Economics, Vol.67, pp.221-240. 